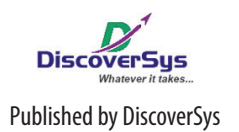

Published by DiscoverSys

\section{Predisposing, Supporting and Driving Factors for Utilization of Adolescent Care Health Services in South Kuta}

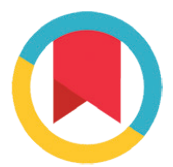

CrossMark

\section{ABSTRACT}

Background and purpose: Targetted adolescent health services (PKPR) at the South Kuta Health Center have been offered since 2007. However, these are rarely accessed (less than 5 visits per month) whereas adolescent health incidents/concerns such as abortion, HIV/AIDS and drug use are reported to increase. This study aimed to determine the predisposition, supporting and reinforcing factors of PKPR utilization. Methods: The study was qualitative and conducted among 27 students in four sessions of focus group discussions, as well as indepth interviews with four key informants. Data collected consisted of knowledge, attitudes and views of participants on PKPR facilities. Thematic analysis was conducted to identify predisposition, supporting and reinforcing PKPR utilization factors.
Results: The study participants intimated that their knowledge about PKPR was low, although they recognised the benefits of such service. They also acknowledged that the quality of facilities/infrastructure were poor, the IEC materials were interesting but the deliverance was unclear and the attitude of providers was unfriendly. Funds, inappropriate clinic hours and labor provided were minimal. Schools, health centers and the government health office strongly supported PKPR activities and the role of peer counselors. School health programs also encouraged students to take advantage of PKPR.

Conclusion: Local schools, health centers and the government health office were supportive of PKPR activities, however the student's knowledge about PKPR was low because coverage of PKPR was very limited.

\title{
Faktor Predisposisi, Pendukung dan Pendorong Pemanfaatan Pelayanan Kesehatan Peduli Remaja di Kuta Selatan
}

${ }^{1}$ Public Health Postgraduate Program Udayana University, ${ }^{2} S$ chool of Public Health Faculty of Medicine Udayana University, ${ }^{3}$ Department of Community and Preventive Medicine Faculty of Medicine Udayana University

*Correspondence to: Rini Winangsih, Public Health Postgraduate Program Udayana University

renarafael12@gmail.com
Hasil: Peserta diskusi dan responden mengemukakan bahwa PKPR bermanfaat bagi mereka namun pengetahuan siswa mengenai PKPR sangat kurang. Masalah yang dikemukakan ialah sarana dan prasarana tidak lengkap, materinya cukup menarik tetapi penyampainnya kurang jelas dan sikap petugas yang kurang ramah. Dana, waktu dan tenaga yang disediakan dianggap kurang, muda-mudi di tingkat desa belum dapat mengakses layanan PKPR karena jam layanan puskesmas yang terbatas. Sekolah, puskesmas dan dinas kesehatan dinilai sangat mendukung kegiatan PKPR dan peran konselor sebaya dinilai sangat baik. Lomba usaha kesehatan sekola (UKS) juga dinilai dapat mendorong siswa untuk memanfaatkan PKPR

Simpulan:Sekolah, puskesmas dan dinas kesehatan sangat mendukung PKPR, namun pengetahuan siswa tentang kesehatan remaja sangat kurang karena cakupan layanan PKPR yang amat terbatas. 


\section{PENDAHULUAN}

Remaja merupakan investasi masa depan bangsa karena merupakan generasi penerus yang sangat berharga bagi kelangsungan pembangunan di masa mendatang, akan tetapi kemajuan teknologi dan penyebaran informasi membawa dampak negatif permasalahan remaja seperti kejadian aborsi, penularan HIV-AIDS dan penggunaan narkoba yang semakin meningkat. ${ }^{1}$

Laporan UNICEF menunjukkan terjadi tren yang mengkhawatirkan karena peningkatan jumlah kematian remaja yang berusia 10-19 tahun akibat HIV/AIDS di seluruh dunia, yaitu 71.000 remaja pada tahun 2005 meningkat menjadi 110.000 jiwa pada tahun 2012. ${ }^{1}$ Data BKKBN pada tahun 2013, menunjukkan bahwa sebanyak 4,38\% remaja usia 10-19 tahun tahun telah melakukan aktivitas seks pra nikah. ${ }^{2}$ Pemerintah menerapkan beberapa strategi untuk mengatasi permasalahan kesehatan reproduksi remaja dan salah satu strateginya adalah Program Pelayanan Kesehatan Peduli Remaja (PKPR). ${ }^{3}$ Pelayanan Kesehatan Peduli Remaja adalah suatu program yang dikembangkan oleh Kementerian Kesehatan RI sebagai upaya untuk meningkatkan status kesehatan remaja berbasis pelayanan kesehatan primer di puskesmas. ${ }^{3}$

PKPR di Puskesmas Kuta Selatan Kabupaten Badung Provinsi Bali sudah berjalan sejak tahun 2007, akan tetapi pemanfaatannya sangat sedikit yaitu pada tahun 2014 rata-rata kurang dari lima kunjungan per bulan walaupun permasalahan remaja cukup tinggi. Laporan penelitian menunjukkan bahwa dari 327 remaja di Badung, 5\% (16 orang) diantaranya pernah berhubungan seks pada usia 14-19 tahun, dan dari enam belas orang tersebut, satu pernah terkena infeksi menular seksual dan dua pernah hamil hingga berakhir dengan aborsi. ${ }^{4}$ Penelitian lainnya di Bali pada tahun 2013 menyebutkan bahwa dari 633 pelajar, $10-31 \%$ remaja yang belum menikah pernah punya pengalaman berhubungan seks. ${ }^{5}$ Permasalahan lain yaitu pengguna narkoba di Bali dilaporkan sebanyak 1,8\% dari total penduduk atau 55.553 orang. ${ }^{6}$ Data tersebut menunjukkan bahwa di Bali telah terjadi peningkatan yang signifikan terkait dengan masalah kesehatan reproduksi dan masalah lainnya pada remaja. Di Indonesia sudah banyak penelitian tentang PKPR, ${ }^{11-13}$ akan tetapi belum ada yang meneliti tentang faktor predisposisi, pendukung dan pendorong pemanfaatan PKPR.

Tujuan penelitian ini untuk mengetahui secara lebih mendalam faktor predisposisi, faktor penghambat serta faktor pendorong pemanfaatan PKPR di wilayah Puskesmas Kuta Selatan.

\section{METODE}

Penelitian ini merupakan penelitian kualitatif, dimana data dikumpulkan dengan cara focus group discussion (FGD) dan wawancara mendalam. ${ }^{7}$ Penelitian ini dilakukan di SMPN 3 Kuta Selatan, SMP Dwijendra dan Puskesmas Kuta Selatan dari Bulan Januari-Maret 2015. Pengumpulan data melalui FGD dilakukan sebanyak 4 kali pada 27 informan kunci yaitu siswa Organisasi Siswa Intra Sekolah (OSIS) laki-laki dan perempuan. Informan dipilih secara purposive yaitu siswa OSIS yang duduk di kelas VII. Wawancara mendalam dilakukan pada informan lain yaitu pemegang program PKPR, wakil kepala sekolah, guru BK dan konselor sebaya. Instrumen penelitian adalah pedoman FGD, pedoman wawancara mendalam dan lembar observasi untuk melihat kelengkapan sarana dan prasarana PKPR. FGD dan wawancara mendalam direkam dengan menggunakan alat perekam dan kemudian dibuatkan transkripnya.

Analisis data dimulai dengan membuat transkrip dari hasil rekaman, kemudian memberikan kode (coding), selanjutnya memasukkan ke dalam matriks berdasarkan tema-tema yang telah ditentukan sebelumnya. Tema-temanya adalah faktor predisposisi, faktor pendukung dan faktor pendorong pemanfaatan PKPR. Hasil penelitiannya disajikan berdasarkan tema sentral yang muncul dalam analisis. ${ }^{8}$ Penelitian ini telah mendapatkan kelaikan etik dari komisi etik Fakultas Kedokteran Universitas Udayana/Rumah Sakit Umum Pusat Sanglah.

\section{HASIL DAN DISKUSI}

Secara umum hasil penelitian ini menunjukkan bahwa pemanfaatan pelayanan PKPR dipengaruhi oleh faktor-faktor predisposisi, faktor-faktor pendukung serta faktor-faktor pendorong. Uraian lebih lengkap mengenai ketiga faktor tersebut dapat dilihat dalam uraian berikut ini.

\section{Faktor predisposisi}

Hasil FGD menunjukkan bahwa pengetahuan remaja mengenai PKPR sangat kurang, sebagian besar siswa menganggap keberadaan PKPR hanya ada di sekolah saja, namun ada beberapa siswa yang menganggap bahwa keberadaan PKPR juga ada di puskesmas dan di desa-desa. Menurut hasil wawancara mendalam dengan pemegang program PKPR, program ini ada di sekolah dan puskesmas. Sebagian besar remaja tidak mengetahui pengertian PKPR, mereka hanya tahu PKPR adalah program untuk remaja. Siswa tidak mengetahui seluruh kegiatan PKPR, sebagian 
besar dari mereka mengetahui, bahwa kegiatan di sekolah yaitu penyuluhan, di puskesmas untuk berobat, sedangkan untuk pelayanan konseling mereka tidak mengetahuinnya. Siswa mendapatkan informasi pelayanan PKPR dari sosialisasi yang diadakan oleh puskesmas pada saat masa orientasi siswa (MOS) dan saat lomba usaha kesehatan sekolah (UKS).

Hasil FGD menunjukkan bahwa keberadaan PKPR sangat penting bagi remaja karena membantu menyelesaikan permasalahnnya, seperti masalah kesehatan reproduksi dan permasalahan lain terkait remaja. Seandainya siswa mengetahui bahwa di puskesmas dan di sekolah ada layanan konseling, mereka akan konseling saat ada masalah. Siswa berharap supaya program PKPR tetap berlanjut dan puskesmas lebih sering ke sekolah untuk mensosialisasikan program PKPR, meleng- kapi sarana dan prasaran untuk menunjang kegiatan. Dalam penyampaian materi PKPR petugas diharapkan lebih ramah serta menggunakan bahasa yang mudah dimengerti.

Sebagian besar siswa berharap bahwa selain di sekolah dan puskesmas, seharusnya PKPR ada di masyarakat. Guru Bimbingan Konseling (BK) dan wakil kepala sekolah berharap puskesmas lebih agresif untuk meningkatkan pembinaan dan kegiatan di sekolah, dan saat penjaringan diharapkan puskesmas datang mendampingi sekolah untuk pemeriksaan siswa. Pemegang program mengharapkan PKPR ini tetap berlanjut, pelayanan kesehatan bisa terjangkau oleh semua remaja termasuk teruna-teruni (muda-mudi) dan remaja masjid. Perlu penambahan petugas khusus dan untuk sekolah diharapkan melengkapi sarana dan prasarana di UKS dan melaporkan kasus remaja. Di puskesmas diharapkan ada ruang khusus remaja dan dinas diharapkan memberi bantuan dana serta kelengkapan sarana dan prasarana. Kutipan pernyataan informan dapat dilihat pada uraian dibawah ini.

"Menurut saya keberadaan PKPR itu bermanfaat, mungkin karena kurang memahami, supaya masyarakat lebih tahu dan lebih paham maka harus diperbanyak juga"

(FGD 3A S3KS)

"Saya kurang tahu pengertian PKPR, hanya tau kegiatan untuk remaja"

(FGD 2A SDJ)

"Kalau di puskesmas ada PKPR, jika ada masalah saya mau ke puskesmas"

(FGD 8D S3KS)
"Harapan saya, pelayanan kesehatan bisa terjangkau oleh semua remaja, termasuk trunatruni, remaja masjid, sedikit demi sedikit kita rencanakan kesitu dan program ini Harus ada, tetap harus ada karena remaja adalah generasi penerus kita, gedungnya juga harus dilengkapi, harus ada tenaga khusus dan darbinnya juga tetap"

(WM PKM)

Program PKPR mempunyai sasaran yaitu semua remaja usia 10-19 tahun dan belum menikah. Remaja yang dimaksud adalah remaja yang berada di sekolah maupun di luar sekolah. Mereka yang di luar sekolah bisa melalui karang taruna, remaja masjid dan perkumpulan remaja lainnya. ${ }^{9}$ Perbedaan persepsi antar siswa tentang keberadaan PKPR dikarenakan kurang maksimalnya sosialisasi tentang PKPR, sehingga tidak semua mengetahui keberadaannya. Hal ini sesuai dengan teori persepsi, bahwa faktor-faktor yang menyebabkan seseorang menerima suatu stimulus yaitu faktor internal dan faktor eksternal. Faktor eksternal melekat pada obyeknya, dimana salah satu faktor eksternal adalah informasi baru dan sebagian faktor internal adalah pengetahuan dan harapan. ${ }^{10}$

Meskipun pengetahuan dan informasi tentang program PKPR sangat kurang tetapi harapan mereka sangat besar terhadap perbaikan dan keberlangsungan PKPR. Hal ini juga didukung oleh pernyataan informan kunci melalui wawancara mendalam. Mereka mempunyai harapan yang sangat besar terhadap perbaikan dan keberlangsungan program PKPR, sehingga dengan harapan yang besar tersebut menyebabkan persepsi yang positif terhadap program PKPR dan mendorong untuk memanfaatkan pelayanan tersebut. Hal ini juga sejalan dengan penelitian pada tahun 2009, yang menyebutkan bahwa pengetahuan mempengaruhi sikap responden terhadap pemanfaatan PKPR di SMPN 01 Sitiung Kabupaten Dharmasraya. ${ }^{11}$

Green et al, melakukan analisis perilaku manusia terkait kesehatan, kesehatan individu atau masyarakat dipengaruhi oleh faktor di luar perilaku dan faktor perilaku, sedangkan perilaku itu sendiri dibentuk melalui beberapa faktor, diantaranya adalah faktor predisposisi, dimana salah satu faktor predisposisi adalah pengetahuan remaja tentang keberadaan PKPR. ${ }^{10}$ Dalam penelitian ini sebagian besar siswa tidak mengetahui bentuk pelayanan klinik dalam PKPR secara benar, sehingga mempengaruhi perilaku kesehatan mereka yaitu pemanfaatan 
pelayanan kesehatan di puskesmas, mereka tidak memanfaatkan pelayanan klinik tersebut dengan maksimal, sesuai dengan laporan puskesmas dimana kunjungan siswa ke puskesmas kurang dari lima orang per bulan.

\section{Faktor-faktor pendukung}

Hasil wawancara mendalam dengan pemegang program menunjukkan bahwa pelaksanaan kegiatan PKPR hanya di sekolah dan puskesmas. Puskesmas belum menjangkau ke teruna-teruni (muda-mudi) karena akses yang sulit. Hal ini disebabkan belum adanya kerjasama dengan desa serta terbentur pada jam kerja puskesmas. Berdasarkan hasil observasi, peneliti menemukan bahwa sarana dan prasana yang disediakan di masing-masing sekolah berbeda. Ada sekolah yang sudah membagi UKS menjadi dua ruang untuk konseling, akan tetapi ada sekolah dengan ruangan UKS beralih fungsi menjadi gudang. Di puskesmas tidak ada ruang khusus untuk konseling dan pelayanan kesehatan remaja tetapi bergabung dengan poli umum. Pernyataan partisipan dapat dilihat sebagai berikut.

"Selama ini hanya di sekolah dan puskesmas saja, untuk ke teruna-teruni belum, karena kita belum punya akses kesana, rencananya kedepan dengan darbin juga. Untuk ruangan di puskesmas masih jadi satu dengan poli umum"

(WM PKM KS)

Hasil wawancara mendalam dengan wakil kepala sekolah, menunjukkan bahwa di sekolahnya tidak memiliki konselor sebaya. Kondisi tersebut sesuai dengan peryataan pemegang program, bahwa ketidakmerataan pembentukan konselor sebaya dikarenakan kurangnya dana, waktu, serta tenaga dari puskesmas. Hasil FGD menunjukkan kegiatan PKPR dianggap cukup menarik dari segi materinya sehingga siswa antusias dalam mengikuti kegiatan. Menurut siswa, pelaksanaan kegiatan PKPR di sekolah adalah kegiatan penyuluhan, pembentukan konselor sebaya, sosialisasi dan skrining. Kegiatan di puskesmas hanya untuk berobat saja, sedangkan untuk konseling semua siswa tidak mengetahuinya. Uraian tentang pernyataan partisipan dapat dilihat dalam uraian di bawah ini.

"Kegiatannya menarik dan tentu sangat menyenangkan karena kegiatan PKPR seru, saya suka kegiatan sosial. Kegiatannya berupa penyuluhan, pelatihan konselor dan banyak lagi yang lainnya"

(FGD 4C S3KS)
"Untuk dana biasanya diambilkan dari dana BOK, tapi itu tidak cukup. Terus untuk pembentukan konselor membutuhkan waktu yang lama dan tenaga yang banyak sehingga takut mengganggu PBM"

(WM PKM KS)

Hasil FGD menunjukkan bahwa saat penyuluhan PKPR, materi yang disampaikan yaitu tentang kesehatan reprodusi, HIV/AIDS dan narkoba. Menurut mereka cara penyampaian materinya menarik akan tetapi ada kendala dalam pelaksanaanya, antara lain siswanya terlalu banyak, tidak semua dapat mengikuti karena keterbatasan ruangan, bahasa yang digunakan susah dimengerti dan sikap petugas tidak begitu ramah. Cara penyampaian materi tersebut dalam bentuk ceramah tanya jawab dengan menggunakan proyektor disertai gambar-gambar dan posterposter. Pernyataan partisipan dapat dilihat dalam uraian berikut.

"Kurang dengar karena siswanya terlalu banyak, terlalu ribut tapi teman saya juga ada yang gak ikut katanya gak kebagian tempat"

(FGD 2A SDJ)

Dalam pelayanan PKPR, sarana dan prasarana yang seharusnya ada di puskesmas yaitu adanya ruang untuk konsultasi dan sesuai alur model pelayanan PKPR. Di sekolah seharusnya ruang UKS dibagi menjadi dua yaitu laki-laki dan perempuan, penyuluhan diadakan di kelas-kelas menggunakan proyektor, terdapat konselor sebaya di masingmasing sekolah dan ada alat-alat permainan. ${ }^{9}$

Berdasarkan hasil observasi di SMP, pelaksanaan penyuluhan sudah diadakan di kelas-kelas, dengan menggunakan proyektor, sudah dibentuk konselor sebaya, dan UKS juga sudah dibagi menjadi dua ruangan yaitu laki-laki dan perempuan, akan tetapi di sekolah lain UKS beralih fungsi menjadi gudang, alat-alatnya tidak terawat, belum ada konselor sebaya, ruangan penyuluhan tidak memenuhi kapasitas dan tidak tersedia alat permainan. Selama ini pelaksanaan PKPR tergantung kondisi di masing-masing sekolah, karena puskesmas tidak memiliki anggaran khusus untuk program PKPR.

Kondisi tersebut sesuai dengan penelitian terdahulu yang menyebutkan bahwa pelaksanaan program PKPR di Puskesmas Kabupaten Tegal belum memenuhi kriteria pelayanan remaja seperti yang ditetapkan Kementerian Kesehatan RI karena berbagai penghambat antara lain kurangnya dukungan sarana dan prasarana, tidak meratanya pembentukan konselor sebaya serta minimnya dana dan tenaga untuk kegiatan PKPR. ${ }^{12}$ 
Ketidakmerataan pembentukan konselor sebaya di tiap sekolah dikarenakan keterbatasan waktu, dana dan tenaga. Hal serupa juga sejalan dengan penelitian kualitatif lain di Kecamatan Buleleng, yang menyebutkan bahwa program PKPR yang dicanangkan Puskesmas Buleleng 1 sebagian besar sudah terlaksana dengan baik, namun masih ada satu sasaran yang belum tercapai yaitu pembentukan konselor sebaya serta belum maksimalnya sosialisasi kepada remaja secara luas. ${ }^{13}$

\section{Faktor- faktor pendorong}

Hasil FGD menyatakan adanya dukungan dari sekolah yaitu berupa dukungan dana untuk kegiatan, melengkapi sarana dan prasarana serta menyediakan waktu untuk kegiatan. Wakil kepala sekolah menyatakan sekolah selalu mendukung semua kegaitan yang positif terutama untuk meningkatkan kesehatan siswa. Sebagian besar siswa juga menyatakan bahwa peran konselor sebaya selama ini sangat baik, mereka menolong teman yang sakit, membantu merujuk ke puskesmas, berjaga di UKS dan sebagian kecil mengetahui fungsi konselor untuk konseling. Meskipun sekolah sudah ada kerjasama dengan puskesmas, akan tetapi menurut guru BK, jika ada siswa yang sakit jarang dirujuk ke puskesmas karena banyak orang tua siswa yang keberatan. Sebagian besar orang tua siswa mempunyai tanggungan dengan perusahaan. Jika ada siswa yang bermasalah, sekolah biasanya menyelesaikan di sekolah sehingga jarang dirujuk ke puskesmas. Beberapa pernyataan responden dapat dilihat dalam uraian berikut ini.

"Sekolah meminta tim PKPR untuk datang kesini dan melatih siswa agar lebih berpengetahuan, dan sekolah juga menyediakan waktu"

(FGD 1B S3KS)

"Diberikan waktu untuk penyuluhan dan diijinkan mengikuti"

(FGD 3A S3KS)

"Selama ini sekolah mendukung semua kegiatan yang positif terutama untuk kegiatan siswa, kami akan all out mendukung kegiatan itu, kami akan menyediakan apa-apa saja yang dibutuhkan, jika tidak ada dana maka akan dibuat skala prioritas"

(WM WKS SDJ)

"Banyak orang tua siswa yang mempunyai tanggungan dengan perusahaan, sehingga sekolah minta ijin dulu jika mau merujuk, biasanya mereka keberatan jika dirujuk ke puskesmas"

(WM PKM KS)
Berdasarkan hasil wawancara dengan pemegang program, menyatakan bahwa dinas kesehatan selama ini mendukung kegiatan dengan menyumbangkan kit UKS untuk sekolah, materi serta perlengkapan, akan tetapi tidak ada anggaran khusus serta tenaga khusus sehingga kegiatan PKPR tidak dapat terlaksana dengan semestinya. Hasil FGD menunjukkan bahwa materi yang disampaikan dalam kegiatan cukup menarik, akan tetapi sikap petugas dinilai kurang ramah dan menggunakan bahasa yang kurang dimengerti siswa. Adanya lomba UKS juga mendorong siswa untuk aktif dalam kegiatan PKPR di sekolah. Pernyataan informan dapat dilihat dari pernyataan berikut ini.

"Selama ini Dinas Kesehatan mendukung, mereka menyediakan UKS kit, materi dan brosur-brosur, leaflet, tetapi tidak ada anggaran dana khusus dan tenaga khusus sehingga tugas kita jadi rangkap"

(WM PKM KS)

"Sebetulnya menarik, tapi ada yang kurang, petugas puskesmasnya ngomongnya banyak berbelit-belit"

(FGD 4B S3KS)

Green et al, melakukan analisis perilaku manusia terkait kesehatan individu yang dipengaruhi oleh faktor di luar individu. Fakor di luar individu dipengarui oleh beberapa faktor diantaranya faktor pendorong yaitu dukungan untuk kegiatan PKPR ${ }^{14}$ Minimnya pemanfaatan PKPR dipengaruhi jam sekolah yang tidak sesuai dengan jam buka puskesmas. Kebijakan dari sekolah dan sikap petugas kesehatan terkait pelayanan klinik dalam PKPR, juga menjadi faktor pendorong untuk tidak memanfaatkan pelayanan klinik. Suatu keseimbangan antara berbagai kekuatan pendorong, dan berbagai kekuatan penahan membentuk perilaku seseorang, pernyataan tersebut sesuai dengan teori Lewin. ${ }^{15}$

Kondisi di atas juga dikarenakan puskesmas kurang maksimal dalam melaksanakan progran PKPR. Informasi tetang PKPR hanya diberikan satu tahun sekali dan itupun dalam kondisi ruangan yang tidak memadai (terlalu banyak peserta) sehingga suasananya tidak kondusif dan informasinya tidak terserap dengan maksimal. Seharusnya pemberian informasi PKPR dilaksanakan minimal dua kali setahun dan di dalam kelas sesuai dengan kapasitas ruangan. Hal ini juga sesuai dengan konsep pengetahuan, dimana faktor yang berpengaruh terhadap pengetahuan adalah informasi, daya ingat, salah penafsiran, kognitif, minat dan sumber informasi. ${ }^{16}$ Jika dikaitkan dengan konsep tersebut 
terlihat bahwa dalam penyuluhan, informasi yang mereka dapatkan kurang maksimal, kemudian mereka pernah mendapat materi saat SD, akan tetapi mereka sudah lupa. Sumber Informasi tentang PKPR, yaitu dari petugas puskesmas. Penyampaian materi cukup menarik akan tetapi sikapnya kurang ramah. Menurut Kemenkes RI tahun 2011, pelaksanaan program PKPR di sekolah seharusnya ada pelatihan konselor sebaya, dimana konselor sebaya sendiri adalah pendidik sebaya yang punya komitmen dan motivasi yang tinggi untuk memberikan konseling dalam program PKPR bagi kelompok siswa di sekolah dan melaksanakan kegiatan terkait UKS.

\section{SIMPULAN}

Dari penelitian ini dapat disimpulkan bahwa pengetahuan siswa mengenai PKPR sangat kurang, hal ini dikarenakan kurangnya sosialisasi dan suasana yang kurang kondusif saat sosialisasi. Informan menganggap kegiatan PKPR ini bermanfaat bagi remaja dan mereka berharap PKPR tetap berlanjut serta lebih sering lagi diadakan sosialisasi. Bentuk kegiatannya menarik akan tetapi perlu di adakan inovasi. Materi dan penyampaiannya menarik akan tetapi bahasanya perlu diperjelas. Faktor pendukung PKPR diantaranya adalah dukungan sekolah dalam memberikan waktu dan memfasilitasi kegiatan PKPR, materi yang diberikan dianggap sangat menarik, peran konselor sebaya dinilai sangat baik karena membantu teman yang sakit dan konseling. Untuk faktor penghambat pemanfaatan layanan PKPR adalah sarana dan prasarana yang kurang lengkap misalnya tidak adanya ruang konseling khusus, kapasitas ruangan yang tidak memenuhi, minimnya tenaga kesehatan, minumnya dana untuk kegiatan, serta sikap petugas yang kurang ramah.

\section{UCAPAN TERIMA KASIH}

Ucapan terima kasih disampaikan kepada Kepala Puskesmas Kuta Selatan, Kepala Sekolah SMPN
3 Kuta Selatan, Kepala Sekolah Dwijendra serta seluruh informan yang telah membantu terlaksananya penelitian ini.

\section{DAFTAR PUSTAKA}

1. Herman. Remaja dan masalah kesehatan reproduk. 2013 (diakses tanggal 2 Desember 2014). Availeble from URL: http://www.rimanews.com.

2. Kementerian Kesehatan RI. Modul Pelatihan Pelayanan Kesehatan Perduli Remaja (PKPR) bagi Tenaga Kesehatan. Jakarta: Dirjen Bina Gizi dan Kesehatan Ibu dan Anak Kemenkes R; 2011

3. Rohan \& Siyoto. Kesehatan Reproduksi. Yogyakarta: Nuha Medika; 2013.

4. Faturohman. Permasalahan remaja di Bali. Yogyakarta: Fakultas Kedokteran UGM; 2009.

5. Laksmiwati. Transformasi social dan Perilaku Reproduksi Remaja. Yogyakarta: Fakultas Psikologi UGM; 2013.

6. Badan Narkotika Nasional Provinsi Bali. Laporan Badan Narkotika Nasional Provinsi Bali Tahun 2013. Bali; BNN Provinsi Bali; 2013.

7. Bungin, B. Analisis Data Penelitian Kualitatif. Jakarta: PT Rajagrafindo Persada; 2003.

8. Poerwandari, E.K. Pendekatan Kualitatif untuk Penelitian Prilaku Manusia. (ed-3). Jakarta: Perfecta LPSP3 Fakultas Psikologi Universitas Indonesia; 2005.

9. Kementerian Keseharan RI. Modul Pelatihan Pelayanan Kesehatan Perduli Remaja (PKPR) bagi Konselor Sebaya. Jakarta: Dirjen Bina Gizi dan Kesehatan Ibu dan Anak; 2011.

10. Notoatmodjo, S. Promosi Kesehatan dan Perilaku Kesehata. Jakarta: Rineka; 2012.

11. Lola W, Erwinda. Hubungan Pengetahuan dan Sikap Siswa Terhadap Pemanfaatan PKPR di SMPN 01 Sitiung Wilayah Kerja Puskesmas Sitiung 1 Kabupaten Dharmasraya. Padang: Fakultas Kedokteran Universitas Andala; 2009.

12. Hadiningsih, T.A. Analisis Implementasi Program Pelayanan Kesehatan Peduli Remaja. Semarang: Magister Ilmu Kesehatan Masyarakat Universitas Diponegoro; 2010.

13. Arsani, A. Agustini, M.Purnomo, I.. Peran Program PKPR terhadap Kesehatan Reproduksi Remaja Di Kecamatan Buleleng. Bali: Ilmu Olahraga dan Kesehatan Universitas Kesehatan Ganesha; 2013.

14. Notoatmodjo, S. Promosi Kesehatan dan Perilaku Kesehatan. Jakarta: Rineka Cipta; 2012.

15. Notoatmodjo, S. Promosi kesehatan, Teori dan Apliaksi. Jakarta: Rineka Cipta; 2010.

16. Nanda. Nursing diagnoses: definitions and classification 2005-2006. Philadelpia: Nanda International; 2005.

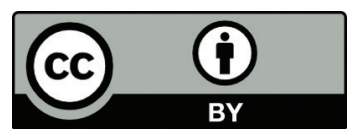

This work is licensed under a Creative Commons Attribution 